\section{(2) OPEN ACCESS}

\title{
Occupational exposure to soft paper dust and mortality
}

\author{
Kjell Torén ำ , ${ }^{1,2}$ Richard Neitzel $0{ }^{3}{ }^{3}$ Gerd Sallsten, ${ }^{2}$ Eva Andersson ${ }^{2}$
}

${ }^{1}$ Occupational and

Environmental Medicine, School of Public Health and Community Medicine, Sahlgrenska Academy, University of Gothenburg, Gothenburg, Sweden ${ }^{2}$ Dept of Occupational and Environmental Medicine, Sahlgrenska University Hospital, Gothenburg, Sweden ${ }^{3}$ Department of Environmental Health Sciences, University of Michigan, Ann Arbor, Michigan, USA

\section{Correspondence to} Professor Kjell Torén,

Occupational and Environmental Medicine, School of Public Health and Community Medicine, Sahlgrenska Academy, University of Gothenburg, Gothenburg 40530, Sweden; kjell.toren@amm.gu.se

Received 26 December 2019 Revised 24 February 2020 Accepted 19 March 2020

Published Online First 2 April 2020
ABSTRACT

Objectives Occupational exposure to soft paper dust is associated with impaired lung function. Whether there is an increased risk for asthma or chronic obstructive pulmonary disease (COPD) is unclear.

Methods We studied 7870 workers from three Swedish soft paper mills, and defined high-exposed workers, as having been exposed to soft paper dust exceeding $5 \mathrm{mg} / \mathrm{m}^{3}$ for at least 5 years. The remaining workers were classified as 'low exposed'. Person-years at risk were calculated and stratified according to gender, age and calendar-year. The follow-up time was from 1960 to 2013. The expected numbers of deaths were calculated using the Swedish population as reference and standardised mortality ratios (SMRs) with 95\% Cls were assessed.

Results There was an increased mortality due to obstructive lung disease (asthma and COPD), among high-exposed workers, SMR 1.89, 95\% Cl 1.20 to 2.83, based on 23 observed cases. High-exposed workers had an increased mortality from asthma, SMR 4.13, $95 \% \mathrm{Cl} 1.78$ to 8.14 , based on eight observed cases. The increased asthma mortality was also observed among high-exposed men, SMR 4.38, 95\% Cl 1.42 to 10.2 , based on five observed cases. The asthma mortality among low-exposed workers, both men and women, was not increased. The COPD mortality was not clearly increased among high-exposed workers (SMR 1.52, $95 \% \mathrm{Cl} 0.85$ to 2.50 ).

Conclusion High occupational exposure to soft paper dust increases the mortality due to asthma, and the results suggest that soft paper dust levels in workplaces should be below $5 \mathrm{mg} / \mathrm{m}^{3}$.

\section{INTRODUCTION}

Worldwide, production of soft paper has grown by about one million tons per year in recent years, with mills in China producing approximately one-third of all papers in $2016 .{ }^{1}$ In Sweden, the production of pulp and paper is an important trade, and one of the main products is soft paper. Soft paper is a semimanufactured paper product predominantly made by recycled waste paper, but in many products a considerable amount of fresh pulp is also added. ${ }^{2}$ Soft paper is then used for the production of toilet paper, paper towels and napkins. Soft paper production is a very dusty process, and levels of total dust above $5 \mathrm{mg} / \mathrm{m}^{3}$ were often found during 1980s in Swedish soft paper mills. ${ }^{3}{ }^{4}$ However, during the last decades the dust levels have decreased considerably due to the introduction of exposure controls and process changes. ${ }^{5}$ Dust from soft paper mills

\section{Key messages}

What is already known about this subject?

- Occupational exposure to soft paper dust is associated with impaired lung function. Whether there is an increased risk for asthma or chronic obstructive pulmonary disease (COPD) is unclear.

\section{What are the new findings?}

- Occupational exposure to soft paper dust exceeding $5 \mathrm{mg} / \mathrm{m}^{3}$ for at least 5 years increases asthma mortality.

\section{How might this impact on policy or clinical} practice in the foreseeable future?

- The immediate implication is that the occupational exposure limit for paper dust should be below $5 \mathrm{mg} / \mathrm{m}^{3}$.

has been characterised and the main constituents are cellulose fibres and inorganic additives such as kaolin and talc. ${ }^{6}$ In Sweden, soft paper is produced in three large paper mills. The production is labour intensive and women represent a large proportion of the manual workers. The production process is different from other paper mills and historically the exposure levels to paper dust is considerably higher in soft paper mills compared with other paper mills

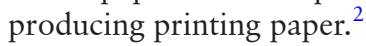

Occupational exposure to dust is associated with an increased risk for chronic obstructive pulmonary disease (COPD) and asthma. ${ }^{7}$ However, whether exposure to paper dust, especially soft paper dust, increases the risk for asthma and COPD is unclear. We have previously described a twofold (though not statistically significant) increased incidence rate of asthma, in a retrospective questionnaire study from one of the largest soft paper mills in Sweden. ${ }^{8}$ Further, we found in a case-control study an increased mortality from obstructive lung disease among workers in another large soft paper mill. ${ }^{9}$ Hence, there are indications of an increased mortality risk for obstructive lung disease among workers exposed to paper dust, but there is a lack of prospective, longitudinal studies in this field. In addition, there are cross-sectional studies indicating that heavily exposed workers have impaired pulmonary function, but dust levels below $5 \mathrm{mg} / \mathrm{m}^{3}$ seem not to impair lung function. ${ }^{3-5} 10-12$

In this paper, we present all-cause and causespecific mortality in a large cohort of workers from all three Swedish soft paper mills. A specific 
Table 1 Characteristics of the three included soft paper mills and number of included workers

\begin{tabular}{|c|c|c|c|c|c|c|c|c|}
\hline \multirow[b]{2}{*}{ Mill } & \multirow[b]{2}{*}{ Start of soft paper production } & \multirow[b]{2}{*}{ Inclusion period } & \multicolumn{3}{|c|}{ Included women } & \multicolumn{3}{|c|}{ Included men } \\
\hline & & & $\mathrm{N}$ & Person-years & Deceased & $\mathrm{N}$ & Person-years & Deceased \\
\hline A & 1940 & 1960-2008 & 1315 & 49648 & 351 & 2054 & 72027 & 703 \\
\hline B & 1943 & 1960-2008 & 1048 & 38106 & 236 & 2042 & 77926 & 866 \\
\hline C & 1947 & 1960-2008 & 764 & 28052 & 176 & 647 & 22955 & 204 \\
\hline Total & NA & NA & 3127 & 115805 & 763 & 4743 & 172908 & 1773 \\
\hline
\end{tabular}

NA, not applicable.

aim was to study whether the mortality from obstructive lung diseases, asthma and COPD, was increased in relation to exposure to soft paper dust.

\section{MATERIALS AND METHODS Study population}

This cohort comprises workers from three soft paper mills in Sweden. The characteristics of the cohort and the mills and the number of included workers and deceased workers, stratified for gender, are presented in table 1. In Sweden, soft paper production started at mill A in 1940. A few years later mill B started on a small scale, but the production of soft paper increased considerably in 1960 in both mills. Both mills previously produced other kinds of paper and also sulfite pulp; this production ended in 1967. In third mill, mill C, the soft paper production started in 1947. Mill C was not included in our previous studies.

We had access to the personnel files from all three mills, and all workers employed for at least 1 year between 1960 and 2008 were included in the cohort. We extracted the personal data for each cohort member from the files, including the unique personal identification number and employment history (period of employment, department and occupation) at the mill. A total of 8624 workers were available, of which 271 were excluded due to incomplete personal identification number or lack of employment data. Workers who worked solely in the office $(n=483)$ were excluded, resulting in a final cohort of 7870 workers potentially exposed to soft paper dust, of which 3127 were women.

\section{Outcome definitions and follow-up}

The start of the follow-up for this mortality study was 1960, or later, if the first employment was after 1960. The cohort was followed until death or until 2013, whichever came first. We calculated employment time as start of employment to end of last employment or end of cohort period. The cohort was matched with the Swedish Cause of Death Register. The period covered the seventh, eighth, ninth and tenth revisions of the International Classification of Diseases (ICD), and the codes used are summarised in table 2.

\section{Exposure assessments}

In all mills area and personal sampling of total dust was conducted starting in the early 1970s. We have previously shown that total dust in soft paper mills can be used as a proxy for soft paper dust. ${ }^{6}$ We obtained historical stationary $(n=532)$ and personal $(n=415)$ measurements of total dust from the mills along with historical information about the work and the different departments at the mills. In addition, our research team has made 611 personal measurements at the mills over the time. We then assigned each department a mill-year and calendar-year specific level of soft paper dust from 1960 until 2008, allowing us to assess exposure to soft paper dust for every year for each worker with an estimated mean level of dust $\left(\mathrm{mg} / \mathrm{m}^{3}\right)$. The exposure assessments have been described in more detail in a recent publication. ${ }^{13}$ Due to variations in exposure across time and duties, most workers were classified into more than one exposure category over the study period. The exposure assessments are presented in table 3. Based on these results we defined 'high-exposed' workers, as those having been exposed to soft paper dust exceeding $5 \mathrm{mg} /$ $\mathrm{m}^{3}$ for at least 5 years. The remaining workers were classified as 'low exposed'.

\section{Statistical analysis}

The person-years at risk were calculated and stratified according to gender, age (5 year bins) and 1-year calendar periods. The first year of employment was not counted and for high-exposed workers, the first 5 years were counted as low-exposed years. The expected numbers of deaths were calculated using the Swedish population as the reference. Standardised mortality ratios (SMRs) were assessed and 95\% CIs were outlined. The risks assessed as SMR were calculated for high-exposed workers and low-exposed workers, and stratified for gender. The analyses were performed using STATA SE V.14 (Stata Statistical Software, Release 14) and SAS V.9.4 (SAS Institute, Cary, North C, USA).

\section{RESULTS}

The cohort consisted of 7870 workers, and of these $2536(32.2$ \%) died during the observation period, 1960-2013 (table 1). The total number of person-years of follow-up was 288713 , of which women comprised 115805 (40.1\%) person-years. The high-exposed group included 478 (15.3\%) of 3127 women, and

Table 2 Diagnostic codes used in the classification of causes of death

\begin{tabular}{|c|c|c|c|c|}
\hline \multirow[b]{3}{*}{ Causes of death } & \multicolumn{4}{|l|}{ ICD } \\
\hline & ICD-7 & ICD-8 & ICD-9 & ICD-10 \\
\hline & 1960-1968 & 1969- 1986 & 1987- 1996 & $\begin{array}{l}\text { From } 1997 \\
\text { onwards }\end{array}$ \\
\hline All malignancies & $140-205$ & $140-209$ & $140-208$ & $\mathrm{C} 00-\mathrm{C} 97$ \\
\hline $\begin{array}{l}\text { Lung, bronchus and } \\
\text { pleura }\end{array}$ & $162-163$ & 162 & 162 & C33-C34 \\
\hline $\begin{array}{l}\text { Cerebrovascular } \\
\text { disease }\end{array}$ & $330-334$ & $430-438$ & $430-438$ & $160-169$ \\
\hline $\begin{array}{l}\text { Ischaemic heart } \\
\text { disease }\end{array}$ & 420 to 422.1 & $410-414$ & $410-414$ & $120-125$ \\
\hline $\begin{array}{l}\text { Obstructive lung } \\
\text { disease }\end{array}$ & $\begin{array}{l}501,502 \\
527.1,241\end{array}$ & $490-493$ & 490-493 & $J 40-J 46$ \\
\hline COPD & $501,502,527.1$ & 491 to 492 & 491 to 492 & $J 43, J 44$ \\
\hline Asthma & 241 & 493 & 493 & J45-J46 \\
\hline All external causes & 800-999 & 800-999 & E800-999 & V01-Y89 \\
\hline
\end{tabular}


Table 3 Characteristics of workers and their years of exposure in different mean exposure levels of soft paper dust among included workers divided on high-exposed and low-exposed women and men

\begin{tabular}{|c|c|c|c|c|c|}
\hline & \multicolumn{2}{|c|}{$\begin{array}{l}\text { High exposed to dust } \geq 5 \text { years }>5 \mathrm{mg} / \\
\mathrm{m}^{3}\end{array}$} & \multicolumn{2}{|c|}{ Low exposed to paper dust } & \multirow[b]{2}{*}{ Total cohort } \\
\hline & Women & Men & Women & Men & \\
\hline Included workers, N & 478 & 648 & 2649 & 4095 & 7870 \\
\hline Age at hire, mean (SD) & $30(12)$ & $28(12)$ & 27 (11) & $27(12)$ & $27(12)$ \\
\hline Employment time, mean (SD) & $18(10)$ & $23(13)$ & $8(8)$ & $13(13)$ & $12(12)$ \\
\hline Follow-up person-years, sum & 19516 & 26800 & 96289 & 146107 & 288713 \\
\hline Ever exposed to $>5 \mathrm{mg} / \mathrm{m}^{3}, \mathrm{~N}$ & 478 & 648 & 609 & 703 & 2438 \\
\hline Years $>5 \mathrm{mg} / \mathrm{m}^{3}$, mean (SD) & $11.5(6.3)$ & $15.3(11.6)$ & $2.3(1.2)$ & $2.2(1.2)$ & $7.5(8.5)$ \\
\hline Cumulative dust exposure $\mathrm{mg} / \mathrm{m}^{3}$ years, mean (SD) & $116(75)$ & 149 (117) & $19(20)$ & $16(23)$ & $34(60)$ \\
\hline \multicolumn{6}{|c|}{ Numbers of workers $(\mathrm{N}$ ) and years (mean) exposed to different levels of total dust } \\
\hline Exposed to mean $0.01 \mathrm{mg} / \mathrm{m}^{3}, \mathrm{~N}$ & 8 & 13 & 60 & 86 & 167 \\
\hline Years $0.01 \mathrm{mg} / \mathrm{m}^{3}$, mean (SD) & $5.4(5.5)$ & $7.2(5.8)$ & $9.3(9.7)$ & $11.9(9.9)$ & $10.3(9.5)$ \\
\hline Exposed to mean $0.1 \mathrm{mg} / \mathrm{m}^{3}, \mathrm{~N}$ & 9 & 50 & 191 & 918 & 1168 \\
\hline Years $0.1 \mathrm{mg} / \mathrm{m}^{3}$, mean (SD) & $3.6(6.4)$ & $9.8(7.5)$ & $6.6(8.1)$ & $12.7(13)$ & $11.5(12)$ \\
\hline Exposed to mean $0.5 \mathrm{mg} / \mathrm{m}^{3}, \mathrm{~N}$ & 37 & 120 & 249 & 1671 & 2077 \\
\hline Years $0.5 \mathrm{mg} / \mathrm{m}^{3}$, mean (SD) & $8.6(7.3)$ & $10.1(10)$ & $6.7(6.7)$ & $11.9(13)$ & $11.1(12)$ \\
\hline Exposed to mean $1.5 \mathrm{mg} / \mathrm{m}^{3}, \mathrm{~N}$ & 212 & 205 & 920 & 1094 & 2431 \\
\hline Years $1.5 \mathrm{mg} / \mathrm{m}^{3}$, mean (SD) & $9.8(7.8)$ & $8.5(7.5)$ & $7.3(6.9)$ & $7.7(7.7)$ & $7.8(7.4)$ \\
\hline Exposed to mean $3 \mathrm{mg} / \mathrm{m}^{3}, \mathrm{~N}$ & 251 & 252 & 1406 & 1206 & 3115 \\
\hline Years $3 \mathrm{mg} / \mathrm{m}^{3}$, mean (SD) & $5.3(2.8)$ & $6.8(5.7)$ & $6.4(6.7)$ & $8.2(11)$ & $7.0(8.3)$ \\
\hline Exposed to mean $7 \mathrm{mg} / \mathrm{m}^{3}, \mathrm{~N}$ & 427 & 584 & 500 & 619 & 2130 \\
\hline Years $7 \mathrm{mg} / \mathrm{m}^{3}$, mean (SD) & $9.9(5.5)$ & $13.1(10)$ & $2.2(1.2)$ & $2.2(1.2)$ & $6.7(7.6)$ \\
\hline Exposed to mean $15 \mathrm{mg} / \mathrm{m}^{3}, \mathrm{~N}$ & 166 & 189 & 195 & 114 & 664 \\
\hline Years $15 \mathrm{mg} / \mathrm{m}^{3}$, mean (SD) & $7.5(7.2)$ & $12.0(11)$ & $1.8(1.0)$ & $2.0(1.2)$ & $6.2(8.1)$ \\
\hline
\end{tabular}

Every worker can be exposed to several different exposure levels during their employment. Mean cumulative dust exposure is also given.

$\mathrm{SD}$, standard deviation.

648 (13.7\%) of the 4743 men. In general, the paper dust levels in the 1970 s to 1980 s were between 5 and $10 \mathrm{mg} / \mathrm{m}^{3}$, but higher levels also existed; $8.4 \%$ of the workers were exposed to levels exceeding $10 \mathrm{mg} / \mathrm{m}^{3}$.

The all-cause mortality was similar to the Swedish population, both among the high-exposed and low-exposed workers (table 4). The cause-specific mortalities from malignancies in the bronchus, lung and pleura, cerebrovascular disease, ischaemic heart disease and all external causes were similar to the Swedish population, in the whole cohort, as well as among men and women (table 4).

There was an increased mortality due to obstructive lung disease, defined as COPD and asthma, among high-exposed workers, SMR $1.89,95 \%$ CI 1.20 to 2.83 , based on 23 observed cases (table 4). The estimates were also increased among highexposed women, SMR 2.15, 95\% CI 0.98 to 4.08 as well as among high-exposed men, SMR 1.75, 95\% CI 0.96 to 2.94 . When separating between asthma and COPD, the increased mortality was found in relation to asthma. High-exposed workers had an increased mortality from asthma, SMR 4.13, 95\% CI 1.78 to 8.14 , based on eight observed cases. Increased asthma mortality was also observed among high-exposed men, SMR 4.38, 95\% CI 1.42 to 10.2 , based on five observed cases. High-exposed women also had an increased SMR 3.77, 95\% CI 0.78 to 11.0 ; however, with a wide CI comprising unity and based on three observed cases. The asthma mortality among low-exposed workers, both men and women, was not increased. The COPD mortality was not clearly increased among the highexposed workers overall (SMR 1.52, 95\% CI 0.85 to 2.50) or among high-exposed men (SMR 1.36, 95\% CI 0.62 to 2.58 ) or among high-exposed women (SMR 1.84, 95\% CI 0.67 to 4.00).
Of the eight high-exposed workers who died from asthma, $50 \%(n=4)$ died before the age of 60 years. Of the seven lowexposed workers who died from asthma, $14 \%(\mathrm{n}=1)$ died before the age of 60 years.

\section{DISCUSSION}

This large longitudinal cohort study of soft paper workers provides evidence that high exposure to soft paper dust, that is, over $5 \mathrm{mg} / \mathrm{m}^{3}$ for more than 5 years, is associated with increased asthma mortality, supporting and clarifying relationships observed in previous case-control and cross-sectional studies.

This is the only existing longitudinal cohort study of mortality among workers exposed to soft paper dust. An additional strength is that we have access to detailed measurements of soft paper dust exposure levels and a complete employment history, making it possible to assess the cumulative exposure for each worker. During the 1970s and 1980s the soft paper dust levels were between 5 and $10 \mathrm{mg} / \mathrm{m}^{3}$, but higher levels exceeding $10 \mathrm{mg} / \mathrm{m}^{3}$ also existed. During more recent years the exposure levels were reduced to around $1-2 \mathrm{mg} / \mathrm{m}^{3}$. Our findings in the present study indicate that working for at least 5 years at dust levels exceeding $5 \mathrm{mg} / \mathrm{m}^{3}$ is associated with significant increased asthma mortality, which was not observed among the low-exposed workers with a similar duration of exposure. We chose $5 \mathrm{mg} / \mathrm{m}^{3}$ as the threshold, as previously this level was the Swedish threshold limit value used for paper dust. In addition, impaired lung function due to paper dust exposure seems not to occur at levels below $5 \mathrm{mg} / \mathrm{m}^{3}$. Five years duration was an ad hoc decision.

Previous studies from other parts of the pulp and paper industry mostly comprise pulp and paper mill workers, and these 


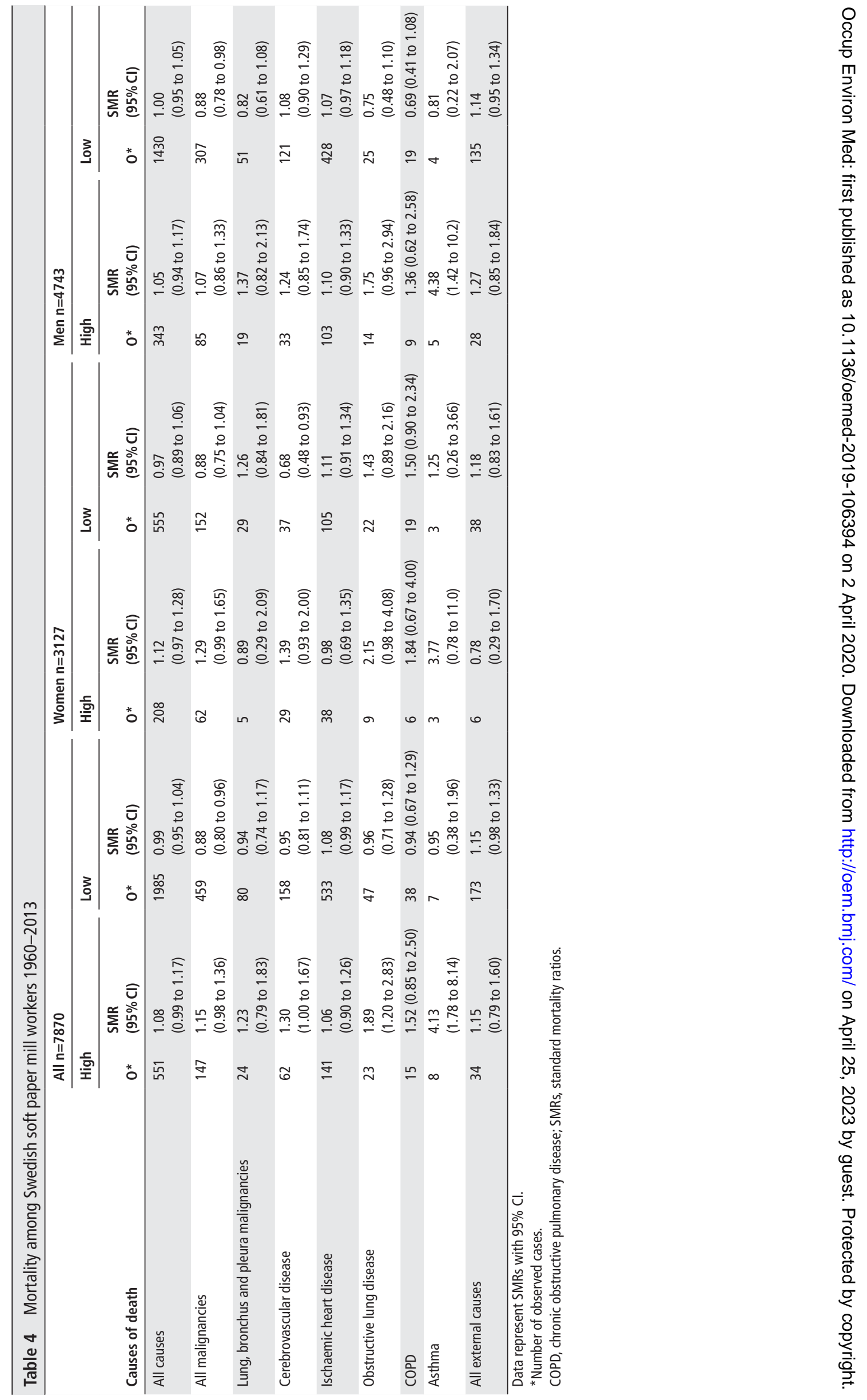


groups have quite different exposures. From such studies it is difficult to conclude about the effects from paper dust. In some studies, not comprising soft paper mills, paper dust exposure from production of printing paper have been investigated. ${ }^{14} 15$ The dust levels were below $3 \mathrm{mg} / \mathrm{m}^{3}$, and there was no increased risk of asthma. ${ }^{14}{ }^{15}$ An additional confounder linked to the production of printing paper is that workers often are exposed to bleaching agents such as previously chlorine, and currently ozone and hydrogen peroxides. ${ }^{16}$

Exposure to dust is increasingly associated with asthma and COPD. ${ }^{7}$ The present study is the first study that links exposure to soft paper dust with increased asthma mortality. Previous studies have described increased mortality due to obstructive lung disease as well as an insignificantly increased incidence rate of asthma, ${ }^{89}$ but conflicting data exist. ${ }^{217}$ A suspected case of occupational asthma due to paper dust (specifically cellulose dust) has recently been described. ${ }^{18}$

The results are also consistent with previous studies showing that high occupational exposure $\left(>5 \mathrm{mg} / \mathrm{m}^{3}\right)$ to soft paper dust is associated with impaired lung function, mainly decreased forced expiratory volume in one second and forced vital capacity. ${ }^{3-512}$ However, in two studies with lower exposure levels $\left(\leq 5 \mathrm{mg} / \mathrm{m}^{3}\right)$, there was no association between exposure to soft paper dust and lung function impairment. ${ }^{1011}$

Increased asthma mortality has previously been linked to occupational exposure to dust, such as wood dust, farming dust and dust in the food industry. ${ }^{19-22}$ Increased asthma mortality associated with certain exposures, such as soft paper dust or other exposures with irritating properties, may reflect that the exposure has triggered fatal asthma attacks leading to death, without being the underlying cause of the disease, that is, causing severe asthma exacerbations. ${ }^{23}$ We do not have information available whether the cases in the present study were triggered by attacks at workplace leading to death, but $50 \%$ of the high-exposed asthma cases died before the age of 60 , compared with $14 \%$ of the low-exposed cases. Still, these results underscore the importance of keeping the exposure to dust and other irritants low.

Exposure to organic dust has been associated with impaired lung function, and exposure to organic dust has been associated with an increased incidence of COPD. ${ }^{24} 25$ We consider soft paper dust to represent a variety of organic dusts, even if it has inorganic constituents. However, the results from the current study are inconclusive regarding the risk of COPD in relation to exposure to soft paper dust.

The study has a number of limitations. There may be misclassification between asthma and COPD. In the period when ICD-8 was used there was a rule that COPD should be given priority as the underlying cause, if COPD and asthma were mentioned together on the death certificate. ${ }^{26}$ This rule was removed in the later ICD versions, and according to a British study the potential misclassification seems to have been important. ${ }^{27}$ There is a possibility that workers with severe asthma could have been classified also as having COPD, which would result in an underestimation of the true asthma risk. However, we consider this misclassification of minor importance, and restricted to a short period of time.

Another weakness is the Healthy Worker Survivor Effect. ${ }^{28}$ Due to the dusty and demanding work in paper mills, less healthy workers will terminate their employment or be transferred to less dusty positions in the mills. It is also likely that the Healthy Worker Survivor Effect will be quite substantial, as high exposure is defined as more than $5 \mathrm{mg} / \mathrm{m}^{3}$ for at least 5 years. This will probably result in weakening of the associations between soft paper dust exposure and outcomes. This is likely further accentuated by our use of the total Swedish population as the comparison group, rather than the occupationally active part of the population.

Another limitation is the lack of information on smoking habits for the entire cohort. In one of the mills, we have information about smoking habits, and high-exposed workers were more often current smokers as compared with low-exposed workers (30\% vs $22 \%){ }^{5}$ Asthma (and COPD) is associated with smoking, so confounding due to smoking is present. ${ }^{19}{ }^{29}$

The strengths of the present study are several. The prospective design with a cohort inclusion based on the personal files in the mills means that the cohort comprises almost all workers who have been employed in these mills, giving us a comprehensive perspective of employment and exposures at the mills. Furthermore, due to our use of personal identification numbers, our medical follow-up has a very high degree of completeness.

Our results provide further evidence that high exposure to soft paper dust increases the mortality due to asthma. The results suggest that dust levels in workplaces should at least be below $5 \mathrm{mg} / \mathrm{m}^{3}$.

Acknowledgements The study was funded by the Swedish Heart and Lung Foundation, Swedish Council for Working Life, Health, and Welfare (FORTE 20020165) and by grants from the Swedish state under the agreement between the Swedish government and the county councils, the ALF agreement, 74570 .

Contributors KT and EA designed the study and interpreted the data. KT wrote the first draft of the manuscript, and is the guarantor of the manuscript. KT and EA have full access to the data about exposure assessments and KT had the final responsibility to submit the manuscript. RN and GS interpreted the data and assisted in the drafting of the manuscript. EA analysed the data. All authors approved the final version the manuscript.

Funding Swedish Heart and Lung Foundation (2002-0165), Swedish Council for Working Life, Health, and Welfare (FORTE) and by grants from the Swedish state under the agreement between the Swedish government and the county councils, the ALF agreement, 74570 .

Disclaimer The lead author (KT) affirms that the manuscript is an honest, accurate and transparent account of the study being reported; that no important aspects of the study have been omitted; and that any discrepancies from the study as planned have been explained.

Competing interests None declared.

Patient consent for publication Not required.

Ethics approval The Gothenburg Committee of Ethics approved the study (Dnr 113-05).

Provenance and peer review Not commissioned; externally peer reviewed.

Data availability statement Data are available upon reasonable request. The data are available by the author. But an access needs a permission from a Swedish Committee of Ethics.

Open access This is an open access article distributed in accordance with the Creative Commons Attribution Non Commercial (CC BY-NC 4.0) license, which permits others to distribute, remix, adapt, build upon this work non-commercially, and license their derivative works on different terms, provided the original work is properly cited, appropriate credit is given, any changes made indicated, and the use is non-commercial. See: http://creativecommons.org/licenses/by-nc/4.0/.

\section{ORCID iDs}

Kjell Torén http://orcid.org/0000-0001-8509-7603

Richard Neitzel http://orcid.org/0000-0001-5500-2589

\section{REFERENCES}

1 FAO. Pulp and paper capacities 2016-2021. Rome: FAO, 2017

2 Torén K, Hagberg S, Westberg H. Health effects of working in pulp and paper Mills: exposure, obstructive airways diseases, hypersensitivity reactions, and cardiovascular diseases. Am J Ind Med 1996;29:111-22.

3 Ericsson J, Järvholm B, Norin F. Respiratory symptoms and lung function following exposure in workers exposed to soft paper tissue dust. Int Arch Occup Environ Health 1988;60:341-5.

4 Järvholm B, Thorén K, Brolin I, et al. Lung function in workers exposed to soft paper dust. Am J Ind Med 1988;14:457-64. 
5 Andersson E, Sällsten G, Lohman S, et al. Lung function and paper dust exposure among workers in a soft tissue paper mill. Int Arch Occup Environ Health 2020;93:105-10.

6 Sahle W, Sällsten G, Thorèn K. Characterization of airborne dust in a soft paper mill. Ann Occup Hyg 1990;34:55-75.

7 Blanc PD, Annesi-Maesano I, Balmes JR, et al. The occupational burden of nonmalignant respiratory diseases. An official American thoracic Society and European respiratory Society statement. Am J Respir Crit Care Med 2019;199:1312-34.

8 Torén K, Järvholm B, Sällsten G, et al. Respiratory symptoms and asthma among workers exposed to paper dust: a cohort study. Am J Ind Med 1994;26:489-96.

9 Thorén K, Järvholm B, Morgan U. Mortality from asthma and chronic obstructive pulmonary disease among workers in a soft paper mill: a case-referent study. $\mathrm{Br} J$ Ind Med 1989:46:192-5.

10 Heederik D, Burdorf L, Boleij J, et al. Pulmonary function and intradermal tests in workers exposed to soft-paper dust. Am J Ind Med 1987:11:637-45.

11 Thorén K, Sällsten G, Bake B, et al. Lung function and respiratory symptoms among workers in a soft paper mill. Int Arch Occup Environ Health 1989:61:467-71.

12 Kraus T, Pfahlberg A, Zöbelein P, et al. Lung function among workers in the soft tissue paper-producing industry. Chest 2004:125:731-6.

13 Neitzel RL, Andersson M, Lohman S, et al. Andersson E. a semi-quantitative job exposure matrix for dust exposures in Swedish soft tissue paper Mills. Am J Ind Med 2020:1-9

14 Torén K, Sällsten G, Järvholm B. Mortality from asthma, chronic obstructive pulmonary disease, respiratory system cancer, and stomach cancer among paper mill workers: a case-referent study. Am J Ind Med 1991;19:729-37.

15 Andersson E, Persson B, Bryngelsson I-L, et al. Cohort mortality study of Swedish pulp and paper mill workers-nonmalignant diseases. Scand J Work Environ Health 2007:33:470-8.

16 Torén K, Blanc PD. The history of pulp and paper bleaching: respiratory-health effects. Lancet 1997:349:1316-8.
17 Kraus T, Pfahlberg A, Gefeller 0, et al. Respiratory symptoms and diseases among workers in the soft tissue producing industry. Occup Environ Med 2002;59:830-5.

18 Knight D, Lopata AL, Nieuwenhuizen N, et al. Occupational asthma associated with bleached chlorine-free cellulose dust in a sanitary pad production plant. Am J Ind Med 2018;61:952-8.

19 Torén K, Hörte LG, Järvholm B. Occupation and smoking adjusted mortality due to asthma among Swedish men. Br J Ind Med 1991;48:323-6.

20 Torén K, Hörte LG. Asthma mortality and occupation in Sweden 1981-1992. Am J Ind Med 1997;31:678-81.

21 Patel 0, Syamlal G, Wood J, et al. Asthma Mortality Among Persons Aged 15-64 Years, by Industry and Occupation - United States, 1999-2016. MMWR Morb Mortal Wkly Rep 2018;67:60-5.

22 Mazurek JM, Henneberger PK. Use of population data for assessing trends in workrelated asthma mortality. Curr Opin Allergy Clin Immunol 2019;19:98-104.

23 Henneberger PK, Redlich CA, Callahan DB, et al. An official American thoracic Society statement: work-exacerbated asthma. Am J Respir Crit Care Med 2011;184:368-78.

24 Matheson MC, Benke G, Raven J, et al. Biological dust exposure in the workplace is a risk factor for chronic obstructive pulmonary disease. Thorax 2005;60:645-51.

25 Lytras T, Kogevinas M, Kromhout H, et al. Occupational exposures and 20-year incidence of COPD: the European community respiratory health survey. Thorax 2018;73:1008-15

26 World Health Organization. International classification of diseases. 8th revision. Geneva, 1967

27 Guite HF, Burney PG. Accuracy of recording of deaths from asthma in the UK: the false negative rate. Thorax 1996;51:924-8.

28 Björ $\mathrm{O}$, Damber $\mathrm{L}$, Jonsson $\mathrm{H}$, et al. A comparison between standard methods and structural nested modelling when bias from a healthy worker survivor effect is suspected: an iron-ore mining cohort study. Occup Environ Med 2015:72:536-42.

29 Rönmark $E$, Lundbäck $B$, Jönsson $E$, et al. Incidence of asthma in adults--report from the Obstructive Lung Disease in Northern Sweden Study. Allergy 1997:52:1071-8. 